\title{
BILATERAL NEGOTIATIONS AND MULTILATERAL TRADE: THE CASE \\ OF TAIWAN-U.S. TRADE TALKS
}

Tain-Jy Chen

Meng-chun Liu

Working Paper 5324

\section{NATIONAL BUREAU OF ECONOMIC RESEARCH 1050 Massachusetts Avenue \\ Cambridge, MA 02138 \\ October 1995}

An earlier draft of this paper was presented at the Sixth Annual NBER East Asian Seminar on Economics held on June 15-17, 1995 in Seoul. We are grateful for the comments made by Takatoshi Ito, Anne Krueger, Sang-Woo Nam, Hank Lim, Koichi Hamada, and other participants at the seminar. We also thank Yungho Weng for providing part of the data used in this study. This paper was prepared for the 1995 NBER East Asian Seminar on Economics and is part of NBER's research program in International Trade and Investment. Any opinions expressed are those of the authors and not those of the National Bureau of Economic Research.

(C) 1995 by Tain-Jy Chen and Meng-chun Liu. All rights reserved. Short sections of text, not to exceed two paragraphs, may be quoted without explicit permission provided that full credit, including (-) notice, is given to the source. 


\title{
BILATERAL NEGOTIATIONS AND \\ MULTILATERAL TRADE: THE CASE \\ OF TAIWAN-U.S. TRADE TALKS
}

\begin{abstract}
This paper reviews the history of bilateral trade negotiations between Taiwan and the U.S. The question posed at the outset is: does bilateralism enhance or jeopardize multilateralism? The U.S.-Taiwan experience seems to suggest a grossly negative answer. Bilateral negotiations for market opening with the threat of unilateral trade sanctions (such as Section 301 action) tend to encourage trade preferences and U.S. negotiators are inclined to accept such preferential arrangements in areas where U.S. domestic interests are homogeneous and concentrated. Even in the case of tariff negotiations where any tariff concessions made by Taiwan are extended to other trading partners on an MFN basis, bilateralism does not necessarily enhance multilateral principles. The scope of tariff concessions made by Taiwan shows a strong bias in favor of the sectors in which the U.S. has a comparative advantage in Taiwan's market and the sectors in which U.S. domestic industries exhibit monopoly power. Meanwhile, U.S. commitments to GATT strengthen its position in bilateral negotiations and help persuade Taiwan, which is not a member of GATT, to make similar concessions.
\end{abstract}

Tain-Jy Chen

Chung-Hua Institution for Economic Research

75 Chang-Hsing Street

Taipei 106

TAIWAN
Meng-chun Liu

Chung-Hua Institution for Economic Research

75 Chang-Hsing Street

Taipei 106

TAIWAN 


\section{Bilateral Negotiations and Multilateral Trade: \\ The Case of Taiwan-U.S. Trade Talks}

\section{Introduction}

It is widely recognized that the multilateral trading system embodied in GATT has played an instrumental role in expanding world trade and supporting the phenomenal economic growth the world has experienced since World War II. Even a non-member like Taiwan has benefited from access to increasingly open markets in industrial countries, particularly the U.S. Immediately after the war, as a hegemonic power, the U.S. had championed multilateralism in world trade and led the way for successive multilateral negotiations for trade liberalization. This effort created international public goods on which even a non-member like Taiwan can ride free.

Since the 1970s, however, the U.S. has resorted with increasing frequency to unilateral measures to solve trade problems. The 1974 U.S. Trade Law provided the U.S. Trade Representative (USTR) with a set of weaponry for practicing unilateralism, such as the section 301 provision, and strengthened safeguard measures.

Armed with these weapons, the USTR undertook bilateral negotiations to achieve "orderly marketing arrangements," such as voluntary export restraints (VER) and the Multifiber Agreement (MFA), to shield domestic U.S. industries from import competition. 
Anti-dumping and countervailing duty cases also became more commonplace, effectively deterring aggressive pricing strategies by importing countries.

Unilateralism was heightened even further in the $1980 \mathrm{~s}$ as the U.S. trade deficit increased to an unprecedented level. Reciprocity and the "level playing field" became catchphrases of U.S. policy-makers. In addition to measures restraining imports, the USTR negotiated vigorously for access to foreign markets, with the target being the former developing countries which had succeeded in industrialization. Bilateral talks on tariff concessions and other market access issues became regular tasks of the USTR. The enactment of the Super 301 and special 301 provisions in the $1988 \mathrm{U} . \mathrm{S}$. Omnibus Trade and Competitiveness Act brought unilateralism to a climax.

It is generally believed that a bilateral approach to world trade problems is inferior to a multilateral approach. A bilateral approach may not even produce a second-best solution (Krueger 1993, p.184). The economic costs of VERs and the MFA have been well documented (see, for example, Hufbauer et al. 1986, de Melo and Tarr 1990, Cline 1990). The problems associated with safeguard measures are also widely discussed (see, for example, Boltuck and Litan 1991). In comparison, the bilateral approach to market opening has not been analyzed in great detail. Krueger's (1993) exploration of the bilateral trade negotiations between South Korea and the U.S. and Ito's(1993) analysis of those between Japan and the U.S., are exceptions. The basic conclusion 
of Krueger's investigation is that forcing Korea to open its market under the threat of the super 301 provision not only represents a departure from GATT principles but also conflicts with the U.S.'s general policy goals toward developing countries. The purpose of this paper is to examine the bilateral trade arrangements between the U.S. and Taiwan, one of its major trading partners targeted for market access in the 1980s. Taiwan is similar to Korea in terms of its asymetrical bargaining power vis-a-vis the U.S. However, Taiwan may hold even fewer bargaining chips than Korea, making it more vulnerable to U.S. threats of trade sanctions. The U.S. generally prevailed throughout the bilateral negotiations. A study of the U.S.-Taiwan case may reveal whether or not the results of bilateral negotiations dominated by the U.S. conform to the multilateral principles espoused by the U.S.

The rest of the paper is arranged as follows. In the next section, we examine the history of bilateral trade arrangements between Taiwan and the U.S., focusing on export restrictions and market access issues other than tariff concessions. The cases in which Taiwan practices trade preference are identified and their background discussed. In section 3 , we present a political economy model to explain the results of the U.S.-Taiwan bilateral negotiations on tariff concessions. It is found that although the USTR may not consciously produce a list of demands for tariff concessions based on the political influences of domestic interest groups, the negotiation outcomes often reflect the 
lobbying power of these groups. The U.S. commitment to the multilateral system, meanwhile, serves as an effective moral persuasion for Taiwan to follow a similar course of trade liberalization.

\section{Bilateral Trade Arrangements between Taiwan and the U.S.}

The U.S. first engaged Taiwan in a bilateral trade agreement in 1962 when Taiwan agreed to voluntarily restrict its exports of cotton textiles and apparel products to the U.S. The agreement was negotiated under the auspices of the Long-Term Arrangement for Cotton Textiles which is primarily an unilateral regulation instituted by the U.S. to curtail textile imports from Japan, Hong Kong, and Korea, as well as Taiwan. Despite this voluntary export restraint (VER) so agreed, Taiwan's exports of textile products to the U.S. continued to increase rapidly, with man-made fiber products accounting for most of the growth. The U.S., in turn, pressured Taiwan, along with Japan, Hong Kong, and Korea, in 1971, to enter new bilateral agreements aimed at limiting the importation of woolen and man-made textile and apparel products. These bilateral actions initiated by the U.S. turned into the Multifiber Agreement (MFA) in 1974 under the purview of GATT, allowing other members of GATT to follow suit in setting geographical quotas to restrict trade in textile and apparel products. The agreement, which is an obvious violation of multilateralism, prevails to this day.

The frequency with which the U.S. used VERs to contain trade 
flow increased substantially in the 1970s. The backdrop of this increased unilateralism was the promulgation of the 1974 Trade Law which empowered the USTR (Section 301 ) to retaliate against U.S. trade partners who engage in unfair trade practices. Fearful of trade sanctions, trade partners, particularly those depending asymmetrically on the U.S. market for export, usually succumbed to U.S. pressure by "voluntarily" restraining their exports deemed (by the U.S.) injurious to an orderly domestic U.S. market. Taiwan agreed to a VER on nonrubber footwear in 1977 and a VER on color television sets in 1979.

It has been shown theoretically and empirically that a VER may not hurt constrained exporters because it raises the price of the exported goods under the imperfect market assumption (Feenstra 1984; Harris 1985; Ries 1993). There is also a possibility that the quality of the export products will shift upward in response to such a quantity restriction, resulting in a upgrading of the industry (Falvey 1979). A study by Aw (1993) estimated the price increase of Taiwanese footwear during the VER-effective period of 1977-1981 to be as high as 18 percent. A study by Aw and Roberts (1986) also confirmed significant quality improvement in Taiwanese footwear exports during the VEReffective period.

It must be noted however, that an abrupt restriction on the expansion of a booming industry just as it begins to show some prominence may undermine the incentive for further investment by existing firms in the industry and deter new entry. This may 
smother the industry before it has a chance to become truly internationally competitive. Taiwan's TV industry, which was subjected to a VER in 1979-1982 and shrank quickly after the mid1980s, might have been a victim of such a "bud-picking" policy.

In analyzing the impact of U.S. VERs on Korean exports, Nam (1993) also expressed concern over the adverse effect of VERs on the long-term competitiveness of the constrained industries. In addition to deferment of domestic investment, he also pointed out that allocation of export quotas may constitute an entry barrier that protects existing inefficient firms.

U.S. unilateralism became even more aggressive in the $1980 \mathrm{~s}$ as the U.S. suffered from increasing trade deficits and extensive unemployment at home. Under the pressure of the National Machine Tool Builders Association, which pleaded for trade protection under Section 232 (safeguarding national security) of the Trade Expansion Act of 1962, the U.S. government engaged Taiwan, along with Japan, in bilateral negotiations aimed at restricting Taiwan's export of machine tools to the U.S. market. The negotiations resulted in another VER agreement which took effect in January 1987. The VER on machine tools was even more damaging to Taiwan's industry than the VERs on textiles, footwear, and TV sets because the machine tool VER limited Taiwan's market share instead of quantity or growth rate. Market share restrictions placed on individual product categories based on previous market performance severely restricted the industry's potential for upgrading from low-end to high-end products. Specifically, the 
VER accord on machine tools gave fairly sizable market shares to Taiwan's companies for conventional items, such as nonnumerically controlled lathes (24.70\%) and milling machines (19.298), but very small market shares to advanced items with good growth potential, such as numerically controlled lathes (3.23\%) and machine centers (4.66\%). The VER, which was originally due to expire in January 1992, was extended for another two years after a lengthy and frictional negotiation in 1992. Whether the VER has succeeded in protecting the U.S. machine tool industry is not clear. It is clear, however, that the VER has suppressed Taiwan's market share along with Japan's, allowing unrestricted competitors, notably Switzerland and Korea, to gain substantial market share during the restriction period.

In addition to VERs, the U.S. has also resorted to safeguard measures to restrict Taiwan's exports into the U.S. market. Between 1980 and 1990, there were seven countervailing duty and 29 anti-dumping cases filed against Taiwan by U.S. industries, making Taiwan one of the top countries among all U.S. trading partners blamed for the plight of U.S. industry. For Taiwan's exporters, which are typically small in size, the lengthy and costly legal process involved in these cases presents an effective deterrent to price competition. 1

The most aggressive series of unilateral assaults launched by the U.S. in the 1980s, however, were to pry open the doors of its trading partners for U.S. access to domestic markets. Many developing countries have thrived on exports to the open U.S. 
market heretofore, and have developed sizable domestic markets of their own which could be reciprocally open to U.S. imports. Therefore, U.S. trade representatives pressured these countries to liberalize their domestic markets. Both Taiwan and Korea were selected as primary targets. The U.S. used preferential tariffs afforded to Taiwanese and Korean exports under Generalized System of Preferences (GSP) as the leverage for bargaining. In fact, the negotiations undertaken were often called "GSP consultations," although the agenda were largely focused on market opening. Ironically, despite continuous concessions granted by Taiwan and Korea, GSP preferences for these two countries were appealed in January 1989. Later on, the U.S. trade representatives switched to Super 301 and Special 301 provisions of the 1988 Trade Act as the main leverage for bilateral bargaining.

The U.S. pressure for access to Taiwan's market was heightened in the second half of the 1980s when the bilateral trade imbalance swelled to a historic level. Because the impulse of import liberalization often intruded into the domain of politically powerful domestic interest groups, trade friction became inevitable. As documented in Table 1, between 1986 and 1988 there were at least four occasions on which Taiwan was on the brink of being subject to unilateral trade sanctions by the U.S.

In May 1986, Taiwan was investigated by the USTR under the provisions of Section 307 of the 1974 Trade Law for its imposition of an export performance requirement on an investment 
project in Taiwan proposed by the Japanese automaker Toyota. According to this performance requirement, Toyota was to export no less than 30 percent of the cars assembled in Taiwan in the initial period, and the export ratio was to exceed 50 percent when production reached full capacity. Fearing that Toyota would "dump" these cars on the U.S. market, the USTR demanded that Taiwan remove the export performance requirement and invoked the Section 307 investigation to stage a credible threat. Taiwan succumbed to the pressure by removing the export performance requirement; but the action also killed the investment project because the existing carmakers in Taiwan lobbied against the Toyota project for fear of being out-competed if Toyota was allowed to sell freely in the domestic market.2

The U.S. also invoked Section 301 investigations twice in 1986, the year that Taiwan's bilateral trade surplus with the U.S. reached a historic record of $\$ 13.6$ billion. In August 1986 , the first Section 301 investigation was undertaken after Taiwan refused to revamp its practice of assessing customs duties on imported goods based on an official price table. Facing an imminent Section 301 retaliation, Taiwan abolished the official price table and began assessing customs duties based on the transaction value.

The first serious trade dispute concerning market access also arose in 1986, when Taiwan and the U.S. could not agree on the tariff levels to be imposed in Taiwan on U.S. cigarettes and the regulations concerning cigarette advertisement in Taiwan. 
Just one year earlier, Taiwan had reluctantly agreed to allow U.S. cigarettes, beer and wine to be imported freely. The dispute on tariffs and advertising led the USTR to invoke the section 301 investigation for the second time in 1986. The action forced Taiwan to lower the tariff level, although Taiwan's regulation on cigarette advertisement were enacted largely unchanged.

Another serious dispute concerning market access arose in 1988 when Taiwan refused to remove an import quota on U.S. turkey meat. Strong protest against imported turkey meat was voiced by Taiwan's chicken farmers who demonstrated in front of the American Institute in Taiwan, the de-facto U.S. embassy in Taipei, and who later staged a street rally which turned into a riot. Despite the strong resistance from local farmers, the Taiwan government agreed to dismantle the import quota after being investigated under the Section 301 provision.

After the enactment of the 1988 U.S. Trade Law, which empowered the USTR with the Special 301 provision, bilateral negotiations between Taiwan and the U.S. focused on the issue of intellectual property rights. The USTR has placed Taiwan on the Priority watch list under the special 301 provision three times since the law took effect (see Table 1). Once placed on the Priority Watch list, Taiwan had to negotiate with the USTR for a settlement which would significantly improve the protection of U.S.-owned intellectual properties within six months or face sanctions. Under this pressure, Taiwan revised its copyright law twice to meet the U.S. demand, with some provisions now exceeding 
international standards in copyright protection. For example, the current version of the copyright law in Taiwan prohibits Taiwanese citizens from importing original works through unauthorized dealers or from third-party markets (i.e., parallel imports).

Nevertheless, confrontation was the exception rather than the norm in Taiwan-U.S. negotiations. ${ }^{3}$ often, Taiwan succumbed to the U.S. pressure without much resistance, particularly when the domestic interest groups at stake lacked political clout. In cases where the domestic interest groups to be affected were politically sensitive, such as agriculture, or politically powerful, such as the insurance and security industries, Taiwan often resorted to trade preference to reduce the impact on domestic industries. Like in the case of Japan, U.S. pressure is sometimes useful in helping dismantle vested interested groups with minimum political costs (Ito 1993), but practice of trade preference incurs extra costs on resources allocation. 4 Trade preference often takes the form of offering exclusive market access to American firms. Since Taiwan was not a member of GATT, it was free to exercise discrimination, although this practice sometimes brought protests from other trading partners, such as the European countries. On such occasions, Taiwan would engage the complainant in a bilateral negotiation for a settlement. since no other trading partner possessed the same kind of asymmetrical bargaining power as does the U.S., bilateral negotiations with non-U.S. trading partners are not as lopsided. 
For the U.S. trade negotiators, who still proclaimed themselves the champions of multilateralism, Taiwan's offer of unilateral trade preference put them in a dilemma. They could accept the offer for the benefit of American industries but at the expense of multilateralism, or they could reject the offer in favor of continued negotiations which were costly and the results uncertain. A simple rule seemed to guide the decisions of U.S. negotiators, that is, to accept the offer when the beneficiary industries in the U.S. were concentrated or politically sensitive, and to reject the offer when the domestic interests were diversified or the benefits from access to Taiwan's market was hard to appropriate.

Table 2 lists some major trade preferences that Taiwan has granted to the U.S., most of which still prevail today. Among them, four are related to agricultural products, including fruit, turkey meat, beef, and grain. The others are related to tobacco, beer, and wine, automobiles, and the insurance and securities industries. Exclusive market access is granted to U.S. fresh peaches and persimmons, turkey meat, and insurance operators. U.S. tobacco, beer and wine are allowed to be imported and distributed through agents designated by the manufacturers whereas other brands can only be imported by the state-owned monopoly producer in Taiwan. U.S. beef classified as "prime" or "choice" by U.S. standards is subject to a lower tariff rate whereas its main competitor, Australian beef, has been subject to a higher tariff rate which applied to low-grade beef. Importation of beef from 
other origin, such as Argentina, is prohibited for physiological and sanitary reasons. U.S. wheat, maize and soybeans, meanwhile, benefit from a subtle preference scheme in which the Taiwanese government has created import cartels for the respective grains and directed these monopsonies to buy from the U.S. At times, The "Buy American" missions organized by these import cartels have even been manipulated to favor particular states of the U.S. In the case of the securities industry, the Taiwanese government has exercised favoritism in granting brokerage licenses to U.S. brokerage firms.

These trade preferences have been effective in tilting economic benefits in favor of U.S. firms. For years, U.S. grain has accounted for more than 90 percent of Taiwan's grain imports. Taiwan is the largest export market for American automobiles in Asia, and there are more U.S.-based insurance operators in Taiwan than indigenous ones.

Trade preferences, however, have also incurred apparent economic costs via trade diversion effects. For example, suppression of cigarette imports from Japan has resulted in widespread smuggling of Japanese brands such as Mild Seven. Exclusive market access for automobiles made in North America and Europe has resulted in large number of Toyota, Honda and other Japanese makes being imported from the U.S. rather than Japan. Locking out of European insurance firms has resulted in insurance policies written by Hong Kong branches of European firms being sold in Taiwan's underground market, causing legal problems. 
In contrast with the issues in which relevant domestic U.S. interests are concentrated, the U.S. has usually insisted on multilateralism on the issues in which U.S. economic interests are dispersed. For example, U.S. negotiators repeatedly turned down Taiwan's offer to enhance protection of U.S. trademarks, patents, and copyrights on an exclusive basis.

In fact, in the area where Taiwan's domestic market is dominated by large conglomerates and state-owned enterprises whose political influence is formidable, the Taiwanese government seems to prefer bilateral agreements with the U.S. to allow exclusive access to American firms (hence partial liberalization) rather than a full-scale liberalization under the multilateral principle.5 At one point, Taiwan even proposed the formation of a free trade area with the U.S. to put all bilateral disputes to rest. The proposal was rejected, however.

\section{The Political Economy of Tariff Concessions}

In addition to bilateral arrangements for constraining Taiwanese exports to the U.S. and for opening Taiwan's market to U.S. exports, the U.S. also engaged Taiwan in negotiations for lowering Taiwanese tariffs on imports. Tariff negotiations are completely consonant with the multilateral principle as all concessions made by Taiwan are extended to all trading partners on MFN basis. The U.S. first engaged Taiwan in bilateral trade talks in 1978, aiming at obtaining concessions from Taiwan in exchange for the U.S. extension to Taiwan of the concessions it 
committed itself to in the Tokyo Round. In other words, the U.S. used bilateral negotiation to incorporate Taiwan, a non-signatory of GATT, into the multilateral system. The talks covered both tariff and non-tariff trade issues. From 1978 until 1989, Taiwan and the U.S. have engaged in tariff negotiations nine times. The negotiations then were recessed when Taiwan declared its intention to apply for GATT membership and filed an official application in 1990. Since bilateral negotiations following Taiwan's GATT application will have important implications for the GATP admitting procedure, the U.S. wisely halted the annual trade talks at that point. 6

The purpose of this section of the paper is to examine the pattern of Taiwan's tariff concessions. From this examination we hope to uncover the political-economic explanations for the U.S. demands for tariff reductions and Taiwan's responses.

Table 2 lists the tariff concessions requested by the U.S. and eventually granted by Taiwan in these nine rounds of negotiations. It can be seen that a total of 1,807 tariff reductions were requested by the U.S., some repetitively on the same items, and a total of 1,314 concessions were actually granted. The success rate was 72.7 percent, although the amount by which the duty was actually reduced on each item might be smaller than the original demand. In addition to tariff concessions so granted, Taiwan also cut tariffs on its own initiatives in order to bring the tariff structure in line with its own objectives, for example, to provide adequate effective 
rates of protection to strategic industries. As a result, the Taiwan government rewrote the tariff law almost every year to bring the tariff schedule up to date. Successive concessions brought the average tariff burden down from 11.3 percent in 1978 to 6.3 percent in 1989.7

The requesting and granting of concessions were not made randomly, they were based on political-economic calculations. Table 4 lists the distribution of concessions across industries. It can be seen that in terms of the sheer number of concessions, the fabricated metal industry (encompassing machinery, electronics, and transport equipment) had the largest number at 333, followed by 291 in the food processing industry, and 224 in the chemical industry. It can also be seen from the second column of the table that the number of tariff items affected was smaller than the number of concessions, indicating that some tariffs were cut repetitively. The last column of the table indicates the proportion of tariff items subject to tariff cut. It can be seen that during the eleven-year negotiations 20.6 percent of all tariff items were negotiated to come down at least once. The efforts of U.S. trade representatives toward reducing Taiwan's trade barriers has to be admired. Among the broadly defined industry categories, the food processing industry witnessed the highest proportion of tariff items targeted for tariff reduction (38.98). This was followed by the wood and paper industry (31.78), and the fabricated metal industry (28.08). A large proportion of agricultural products (24.28) were also earmarked for tariff cut, 
in addition to being frequent targets of negotiations for removal of non-tariff trade barriers.

We conducted a statistical test to see whether these tariff concessions were deliberately selected or randomly chosen. Comparing the frequency distribution of actual tariff concessions made across industries with the frequency distribution of the tariff population across industries, we obtained a chi-squared statistic of 266.6 under the null hypothesis that the two distributions are indistinguishable. Given that there are nine degrees of freedom, the statistic soundly rejects the null hypothesis, implying that the concessions were not made randomly.

Presumably, the U.S. trade negotiators chose items in which U.S. producers possessed a comparative edge in Taiwan's market. And in fact, for the import items targeted by the U.S. for concessions and actually acted upon by Taiwan in the nine rounds of negotiations, the U.S. occupied a market share of 31.6 percent in 1977, one year before the negotiations commenced, compared to its 23.1 percent market share in Taiwan's overall import market that same year. In 1990, one year after the last round of negotiations, the U.S. market share among these conceded import items rose to 45.0 percent whereas the U.S. share in Taiwan's total import was 23.0 percent, virtually unchanged from the 1977 level. It is apparent that the import items targeted for negotiation and ultimately subjected to concession were those whose comparative advantage was moving in favor of the U.S. producers or whose market potential in Taiwan is better for 
American products than the average. Therefore, although the U.S. created public goods by negotiating with Taiwan for tariff reduction, there was an intrinsic bias in the scope of reduction driven by U.S. self-interest. In the following, we will explore the interplay of these self-interests and Taiwan's defense strategy

We envisage a political economy model in which interest groups in the U.S. motivate the U.S. negotiators' demands for specific tariff concessions. Taiwan's negotiators, on the other hand, react to these demands by deciding whether to concede or not based on the political and economic costs at home. Until the later part of the 1980s, Taiwan had a basically autocratic government with limited influence from business interests. While maintaining a harmonious relationship with the U.S. was a predominant policy concern, the Taiwan government's decision rule at this time would probably be to act so as to minimize the adverse effects on economic development with little regard to private business interests at home. Multilateralism was probably of little relevance in bilateral negotiations although it might be used to legitimize the negotiators' positions. For example, before the conclusion of the Uruguay Round of the GATT negotiations, there was no unified rules on agricultural trade. The Taiwan negotiators cited the widespread practices of GATT members in protecting their domestic agricultural products to justify Taiwan's high tariffs. on agricultural products.

Based on the political economy model of trade policy 
formation expounded by Baldwin (1989) and Olson (1965), and considerations of bargaining strategy, we attempted to determine which factors were important in influencing the selection of tariff items that were targeted for negotiation by the U.S. and that were conceded by Taiwan. This was done with a regression model. We include the following variables in analyzing the determination of tariff concessions in bilateral talks. The explanatory variables are divided into two groups, one related to Taiwan and the other related to the U.S.

Taiwan-related variables

Public enterprise (PUB):

Public enterprises are a crucial factor in the determination of Taiwan's structure of trade protection. The sector in which public enterprises have a larger output share is also more heedfully protected by tariff and non-tariff measures (Chen and Hou 1993). Taiwanese government officials are likely to be more determined in defending the interests of public enterprises than private enterprises because demise of public enterprises means deceasing governmental control over economic resources for political expediency. The U.S. counterparts, who understand the importance of Taiwan's public enterprises, may also refrain from attacking sectors pertinent to the interests of public enterprises to avoid acrimony. The variable PUB is measured by the share of public enterprises in the output of each sector.

Employment (EMP): 
In a democratic society, employment means voting power. Most studies suggest that the larger the employment size of the industry, the higher the expected level of protection (Baldwin 1989, p. 122). Taiwan, however, in the period that we studied here, was not yet a mature democratic society. To what extent employment mattered to policymakers and influenced negotiators is an empirical question. EMP is measured by the number of workers in each sector.

Wages (WAGE) :

Wage rate may be an important factor in trade negotiations for two reasons. First, public officials may seek to protect workers whose wages are already relatively low from the market pressures resulting from liberal trade policies out of egalitarian concerns (Baldwin 1989, p. 122). Second, wages are generally positively correlated with skills embodied in workers. As has been demonstrated in the trade literature, worker skills are important determinants of comparative advantage of industrialized countries (Keesing 1966; Baldwin 1971). A high skill endowed, and hence high wage, industry is likely to be an industry in which Taiwan was gaining comparative advantage, as the country was making the transition from a labor-abundant to a labor-shortage economy during the period studied. If Taiwan's officials are concerned about protecting newly emerging industries more than declining industries, they may be more determined to resist trade liberalization in the high-wage sectors. WAGE is 
measured by monthly wage per worker, in terms of NT (Taiwanese currency).

Tariff level (TB):

The U.S. negotiators are likely to target Taiwan's hightariff items for tariff cut. This makes economic sense because the potential benefit from trade creation is high. For example, the U.S. negotiators successfully forced Taiwan to reduce the tariff on imported automobiles from 50 percent to 30 percent, creating a buoyant market for imported cars. It also makes sense in terms of bargaining strategy because the rule of proportionate tariff concessions agreed upon by industrial countries in the Tokyo Round of GATT negotiations provides a "moral" ground for demanding that high tariffs be cut first.

Non-tariff barriers (NTB):

Non-tariff barriers may be used as substitutes or complements for tariffs as measures of trade protection. In Taiwan's case, the two are shown to be substitutes (Chen and Liu 1993). The major non-tariff barriers in Taiwan are licensing requirements, which tend to be more stringent for the sectors in which the tariff levels are lower. During the bilateral negotiations that we studied, licensing control was also a major issue on the negotiation agenda. Through the years of negotiation, licensing control was significantly lessened along with the reduction of tariffs. The U.S. negotiators tended to treat tariff and non-tariff barriers as strategic 
complements and attacked them at the same time. NTB is measured by a weighted index of various non-tariff trade protection measures as described in the Appendix.

In addition, four-firm concentration ratio of the Taiwan industry was tried as an explanatory variable in regression but dropped for lack of significance.

U.S.-related variables

Changes in the U.S. tariff level resulting from the Tokyo Round agreements (UTB):

The U.S. engagement with Taiwan in bilateral negotiations was initially aimed at integrating Taiwan into the Tokyo Round agreements. Therefore, the concessions that the U.S. made in the Tokyo Round might be used as the yardstick for negotiations or the basis for reciprocity. The U.S. might ask Taiwan to make a similar pattern of concessions to make the bilateral talks conform with multilateral agreements. UTB is measured by the percentage change in the nominal U.S. tariff rate as described in the Appendix.

Changes in the U.S.'s effective rate of protection resulting from the Tokyo Round agreements (UERP):

The effective rate of protection may move in the opposite direction from nominal tariff rate. Concessions in nominal tariffs are usually used to gauge the degree of trade liberalization, but the real indicator of government trade policy may be the effective rate of protection. The change in effective rate of protection may truly reflect the U.S. 
government's concerns for domestic industry. It will be interesting to see whether the U.S. government sought to expand export markets through bilateral efforts to aid industries which were losing or gaining in effective rate of protection at home. UERP is also measured in percentage. Industry concentration (UCR4):

It is well documented in the political economy literature that industrial concentration is conducive to lobbying power and hence trade protection. Through bilateral negotiations on non-tariff issues, we have witnessed the formidable political forces of the U.S. industries dominated by oligopolies, such as tobacco, automobiles, insurance, banking, and finance. We expect this influence to carry over to tariff negotiations. UCR4 is measured by four-firm concentration ratio of U.S. industry in 1987.

Revealed comparative advantage (URCA):

Aggregated data presented above suggests that the U.S. gained substantial market shares in the sectors in which tariffs were reduced as a result of bilateral negotiations. We hypothesize that the U.S. negotiators chose the sectors targeted for tariff cut in line with the comparative advantage of various U.S. industries. The index of revealed comparative advantage proposed by Balassa (1977) is used to measure the competitiveness of U.S. products in Taiwan's market. This index is included in the regression analysis to see whether it exerts a systematic impact on the pattern of 
tariff concessions.

We employ the above two sets of variables in a regression analysis to see to what extent each variable can help to explain the likelihood of each Taiwanese industrial sector's being targeted by the U.S. for tariff cuts and the likelihood of being actually cut. The industrial sector is defined at the three-digit level in Taiwan's official industrial classification (CIC). For our purposes here, all import and export commodities listed in the official tariff schedules (at 8-digit level) are first classified into their proper industry sector and then the proportion of those commodity items subjected to tariff cut or to a demand for tariff cut in each round of negotiation is taken as the dependent variable. Since the dependent variable lies between 0 and 1 , we adopt a limited dependent variable model to conduct the regression analysis. The results are reported in Table 5 .

We conducted regressions on two equations separately. The first is the U.S. demand equation, in which the dependent variable measures the proportion of tariff concessions requested by the U.S. negotiators in the beginning of the round. The data on initial U.S. requests are available for the last five rounds of negotiations only (1986-1989). The second equation is the final concessions equation, in which the dependent variable measures the proportion of tariff concessions finally made by the Taiwan government at the end of negotiations. The data on final concessions are complete for all nine rounds.

It can be seen from Table 5 that the set of independent 
variables exhibit different explanatory power in the two equations. For the U.S. demand equation, five independent variables, namely Taiwan's public enterprises (PUB), Taiwan's wage rate (WAGE), Taiwan's tariff level (TB), Taiwan's non-tariff barriers (NTB), and the revealed comparative advantage of U.S. industry (URCA), are shown to be asymptotically significant. The U.S. tends to refrain from demanding tariff concessions in the sectors dominated by public enterprises in Taiwan, and in the sectors in which wages are relatively low in Taiwan. "Respecting" Taiwan's public enterprises and the roles pursued by them was the gesture shown by the U.S. negotiators in the negotiations on nontariff barriers. For example, in the negotiation on market access for U.S. tobacco, the U.S. trade representatives never disputed Taiwan's system of monopolizing tobacco production by the state. The U.S. negotiators also never challenged Taiwan's state-owned oil monopoly. Part of the reason may lie with the favoritism these public enterprises often exercised in the procurement of American products. This attitude may be extended to tariff negotiations.

The fact that the U.S. also refrains from pressuring Taiwan's low-wage sectors for trade liberalization can hardly be conceived of as due to a "social concern" for Taiwan's poor workers. It is more conceivable that the low-wage sectors are also declining sectors in which the U.S. sees little prospect for importing American products. The high-wage sectors are targeted because their potential for sales of U.S. products is good. 
The U.S. assault on the high-tariff sectors came as no surprise. The U.S. also campaigned more vigorously for tariff concessions in the sectors where non-tariff barriers are high. Since many non-tariff barriers also provide the Taiwanese trade administrators with discretionary power to practice trade preference to the advantage of U.S. exporters, the benefits of tariff cuts in this area are likely to be captured by the U.S. producers. This may explain why the U.S. treats tariff and nontariff barriers as strategic complements in bargaining.

It is reassuring that the index of revealed comparative advantage is significantly and positively correlated with the U.S. demands for tariff reduction. This suggests that U.S. negotiators target U.S. products that have been selling well in Taiwan and a tariff reduction may bring disportionately large benefits to the U.S. producers.

It is interesting to note that two variables related to the Tokyo Round agreements, changes in U.S. nominal tariff (UTB) and effective rate of protection (UERP) are not significant factors in shaping the U.S. demands for concession. The degree of industry concentration (UCR4) also turns out to be insignificant. In other words, the U.S. negotiators compile the list of commodities for tariff negotiations mainly based on U.S. comparative advantage, with little regard to the lobbying power of the industry or the U.S. commitments in the Tokyo Round negotiations.

The determinants of the final concessions, supposedly a 
result of the tug of war between the U.S. pressure and Taiwan's counter-pressure, present a different picture. The U.S. request for a tariff concession will be granted only if U.S. pressure is high and the counter-pressure from Taiwan resisting such liberalization is low. In other words, non-priority items on the U.S. demand list may be dropped if they are in strong conflict with Taiwan's interests. On the other hand, non-priority items from Taiwan's perspective may be "sacrificed" to salvage the priority items.

Table 5 shows that in the final concessions equation, public enterprise (PUB) remains significant and negatively related to the probability of tariff concession. This suggests both sides share common interests in sparing state-dominated sectors from tariff concessions. Taiwan's wages (WAGE), however, exert a negative impact on the proportion of tariff reduction, contrary to its correlation with the U.S. demand. The Taiwan government seems to be determined to withstand the U.S. pressures to open up markets of the high-wage sectors, and appears to be successful in doing so. The complete reversal of the pattern of trade liberalization for these sectors is something remarkable, reflecting the strategic importance of Taiwan's high-wage, and probably also high-skilled sectors. Although export promotion is the major Taiwanese government policy toward developing strategic industries in Taiwan, protecting these industries from premature exposure to import competition is also considered important. In this regard, we can sense the importance of industrial 
development concerns on the part of Taiwan in trade negotiations. In fact, Taiwan's Bureau of Industrial Development (BID), which is in charge of industrial policy, played a pivotal role in each round of negotiations.

Existing tariff and non-tariff barriers in Taiwan, which are important determinants for U.S. demands for tariff cuts, are not as important in determining the final outcome of negotiations. The commodities that end up on the final list for tariff reduction are not necessarily high-tariff items. In fact, our analysis reveals that a higher level of tariff on a given item does not even increase the likelihood of that item being actually selected for tariff slicing, as the variable $T B$ is not asymptotically significant. The variable for non-tariff barriers (NTB), however, remain significant at the 108 level, although its statistical contribution to the likelihood of being finally selected for tariff cut is much smaller than the likelihood of being targeted by the U.S. negotiators, judging by the much smaller coefficient estimate for NTB in the final concessions equation.

Interestingly, tariff concessions agreed to by the U.S. in the Tokyo Round and the resulting changes in the effective rate of protection turn out to be important determinants of the final pattern of tariff concessions agreed to by Taiwan, although they do not significantly influence the U.S. negotiators' list of request. The variable of changes in U.S. nominal tariffs (UTB) is shown to be negatively related to the likelihood of tariff 
concession, meaning that for the industries in which the U.S. made more drastic cuts in tariffs, Taiwan also agreed to more cuts. In other words, the U.S. commitment in the multilateral system seem to carry some persuasive power for Taiwan to pledge a similar pattern of concession. Perhaps Taiwan does not want to be seen as a free rider on the multilateral system. On the other hand, final concessions made by Taiwan are positively related to the changes in the effective rate of protection in the U.S. industry (UERP). This implies that the sectors which gain in effective rate of protection in the U.S. are also more likely to gain from easier access to the Taiwan market. This is an apparent "strategic" trade policy aimed at boosting priority industries.

It is also noticeable that the four-firm concentration ratio (UCR4), which is an unimportant factor in the U.S.'s demands for tariff concessions, turns out to be important in deciding the final outcome of negotiations. This implies that the concentrated industries flex their muscle through their lobbying power in bargaining process, making their demands hard for Taiwan's negotiators to resist and hard for the U.S. negotiators to compromise on.

The revealed comparative advantage (URCA) of U.S. industry remains a significant factor in determining the final outcome of bilateral bargaining, although its importance is reduced, judging by a smaller coefficient estimate in the final concessions equation. Resistance by Taiwan's negotiators seems to have attenuated its strength. 
The only variable which turns out to be insignificant in both equations is employment (EMP). It has a correct, negative sign in the final concessions equation, suggesting that Taiwan's negotiators are somewhat concerned about the "voice" of industries with large numbers of employees. This concern has not been transformed into a significant factor for trade negotiators in a new-born democracy, however.

\section{Conclusions}

This paper reviewed the history of bilateral trade negotiations between Taiwan and the U.S. The question we posed at the outset is: does bilateralism enhance or jeopardize multilaterism? The U.S.-Taiwan case suggests that a bilateral approach to obtaining export restriction or market opening by removing non-tariff barriers tends to be in conflict with the multilateral principle. Voluntary export restrictions divert economic benefits to non-restricted exporters at the expense of the importing country and possibly also at the expense of the exporters subject to such restriction. Bilateral negotiations for market opening with the threat of unilateral trade sanctions (Section 301 action) tends to encourage the practice of trade preference. This practice, while rendering maximum benefits to the U.S. industries, is detrimental to multilateralism. It signals to the world that the U.S. is no longer interested in creating public goods for other members of the GATT, and that those who are interested in entering Taiwan's market ought to 
negotiate for their own opportunities. The U.S. is more inclined to accept trade preference in areas where its domestic interests are concentrated. In this connection, state power is employed by oligopolistic firms to circumvent the competition process in gaining access to foreign markets.

Even in the area of tariff negotiations, where any tariff reduction made by Taiwan is applied to other trading partners under the most-favored nation (MFN) principle, bilateralism does not necessarily enhance multilaterism. Since tariff concessions are made selectively, with domestic business interests underlying the selection process, trade liberalization resulting from these negotiations is also biased. On the other hand, we find that multilateral agreements are used as "moral standards" by asymmetrically weak negotiators like Taiwan to defend their position. If the dominant negotiator adheres to the multilateral principles, bilateral negotiations may complement multilateralism. But the temptation to act in one's own self-interest seems to be too great to warrant such a happy outcome.

In any event the prospect of Taiwan's joining WTO in the near future may significantly change Taiwan's bilateral relationship with the U.S. First of all, trade preferences, notably exclusive market access granted to U.S. producers, have to be abolished once Taiwan is admitted to WTO. To offset the loss from an elimination of trade preferences, the U.S. negotiators have been particularly intransigent in demanding drastic tariff cuts in the related product categories during the 
bilateral consultations pertinent to Taiwan's WTO admission. Second, losing the option of preferential trade arrangements reduces the opportunity set for compromise and may make future bilateral negotiations more difficult and more confrontational, although the resultant agreements will be less distortive. Meanwhile, private interests lobbying the U.S. government to negotiate bilaterally for access to Taiwan's market will have to give up their attempts to monopolize Taiwan's market and leave the market-access issue to multilateral organizations. Third, Taiwan will improve its bargaining power, and the legitimacy of its refusal to accept terms of agreement beyond the WTO rules will be strengthened. In cases involving split U.S. interests, Taiwan may even challenge U.S. demands presented through bilateral channels by taking them to the WTO dispute settlement mechanism, making the bilateral approach less effective for the U.S. in the future. In addition, Taiwan may also make use of regional forums, such as APEC, to fortify its position against the U.S. in solving trade-related problems. 
Table 1

Major Unilateral Actions Taken by the U.S. Against Taiwan, 1986-1993

\begin{tabular}{|c|c|c|c|}
\hline Time & U.S. Action & Issue & Taiwan's Concession \\
\hline May 1986 & $\begin{array}{l}\text { Section } 307 \\
\text { investigation }\end{array}$ & $\begin{array}{l}\text { export } \\
\text { performance } \\
\text { restriction on } \\
\text { proposed } \\
\text { Toyota } \\
\text { investment in } \\
\text { Taiwan }\end{array}$ & restriction removed \\
\hline Aug. 1986 & $\begin{array}{l}\text { Section } 301 \\
\text { investigation }\end{array}$ & $\begin{array}{l}\text { customs } \\
\text { valuation }\end{array}$ & $\begin{array}{l}\text { abolishing customs } \\
\text { price tables and } \\
\text { assessing duties } \\
\text { based on transaction } \\
\text { values }\end{array}$ \\
\hline Oct. 1986 & $\begin{array}{l}\text { Section } 301 \\
\text { investigation }\end{array}$ & $\begin{array}{l}\text { marketing } \\
\text { restrictions } \\
\text { on U.S. } \\
\text { tobacco, beer } \\
\text { \& wine in } \\
\text { Taiwan }\end{array}$ & restrictions removed \\
\hline Dec. 1988 & $\begin{array}{l}\text { Section } 301 \\
\text { investigation }\end{array}$ & $\begin{array}{l}\text { quota on } \\
\text { imports of } \\
\text { U.S. turkey } \\
\text { meat to Taiwan }\end{array}$ & quota removed \\
\hline May 1989 & $\begin{array}{l}\text { Special } 301 \\
\text { Priority } \\
\text { Watch list }\end{array}$ & $\begin{array}{l}\text { licensing } \\
\text { requirement } \\
\text { for U.S. films } \\
\text { shown in } \\
\text { Taiwan's } \\
\text { private movie } \\
\text { parlors (MTV) }\end{array}$ & $\begin{array}{l}\text { copyright law } \\
\text { changed to require } \\
\text { licensing }\end{array}$ \\
\hline May 1992 & $\begin{array}{l}\text { Special } 301 \\
\text { Priority } \\
\text { Watch list }\end{array}$ & $\begin{array}{l}\text { copyright } \\
\text { protection of } \\
\text { U.S. computer } \\
\text { softwares }\end{array}$ & $\begin{array}{l}\text { export inspection } \\
\text { scheme installed on } \\
\text { computer hardwares }\end{array}$ \\
\hline May 1993 & $\begin{array}{l}\text { Special } 301 \\
\text { Priority } \\
\text { Watch list }\end{array}$ & $\begin{array}{l}\text { intellectual } \\
\text { property right } \\
\text { protection }\end{array}$ & $\begin{array}{l}\text { copyright law } \\
\text { revised to prohibit } \\
\text { parallel export of } \\
\text { original works }\end{array}$ \\
\hline
\end{tabular}

Source: Compiled from Baldwin, Chen \& Nelson (1995). 
Table 2

Preferential Treatment of U.S. Imports to Taiwan

\begin{tabular}{|l|l|}
\hline Import Items & Preference \\
\hline fresh peaches \& persimmons & exclusive market access \\
\hline tobacco, beer, wine & $\begin{array}{l}\text { exclusive right to distribute in } \\
\text { Taiwan }\end{array}$ \\
\hline turkey meat & exclusive market access \\
\hline beef & $\begin{array}{l}\text { U.s. beef classified as "prime" } \\
\text { or "choice" by U.S. standards is } \\
\text { subject to lower tariffs }\end{array}$ \\
\hline wheat, maize, soybeans & $\begin{array}{l}\text { favored by Taiwan's import } \\
\text { cartels under government } \\
\text { direction }\end{array}$ \\
\hline insurance & $\begin{array}{l}\text { U.S. insurance firms are given } \\
\text { exclusive rights to establish } \\
\text { branches in Taiwan }\end{array}$ \\
\hline securities & $\begin{array}{l}\text { U.S. brokerage firms are favored } \\
\text { in license granting }\end{array}$ \\
\hline automobiles & $\begin{array}{l}\text { imports are allowed for vehicles } \\
\text { made in North America and Western } \\
\text { Europe only }\end{array}$ \\
\hline
\end{tabular}

Source: compiled by authors. 
Table 3

Number of Tariff Concessions Requested by the U.S. and Granted by Taiwan 1978-1989*

\begin{tabular}{|c|c|c|}
\hline Round & Requested & Granted \\
\hline 1978 & 339 & 339 \\
\hline 1981 & 49 & 28 \\
\hline 1984 & 109 & 59 \\
\hline 1985 & 174 & 112 \\
\hline 1986 & 71 & 58 \\
\hline 1987 (Apri1) & 66 & 62 \\
\hline 1987 (August) & 267 & 239 \\
\hline 1988 & 174 & 51 \\
\hline 1989 & 558 & 366 \\
\hline Total & & 1,314 \\
\hline
\end{tabular}

* Classification is based on Customs Import Tariff of the Republic of China (CTRN) code except for 1989 which is based on the Harmonized Commodity Description and Coding System(HS Code). Numbers are counted at the 8-digit level. 
Table 4

Sectoral Distribution of Tariff Concessions by Taiwan 19781988

\begin{tabular}{|l|c|c|c|c||}
\hline \multicolumn{1}{|c|}{ Sector } & $\begin{array}{c}\text { (A) } \\
\text { Number of } \\
\text { Concessions }\end{array}$ & $\begin{array}{c}\text { (B) } \\
\text { Tarifer of } \\
\text { Affected }\end{array}$ & $\begin{array}{c}\text { (C) } \\
\text { of Tariff } \\
\text { Items }\end{array}$ & $\begin{array}{c}\text { (D) } \\
\text { B/C } \\
(\%)\end{array}$ \\
\hline Agriculture & 127 & 76 & 314 & 24.2 \\
\hline Mining & 3 & 3 & 99 & 3.0 \\
\hline Food Processing & 291 & 163 & 419 & 38.9 \\
\hline Textiles\& Apparel & 44 & 35 & 588 & 5.9 \\
\hline Wood\& Paper & 120 & 69 & 218 & 31.7 \\
\hline Chemicals & 224 & 159 & 986 & 16.1 \\
\hline Rubber \& Plastics & 43 & 38 & 153 & 24.8 \\
\hline Basic Metal & 119 & 89 & 520 & 17.1 \\
\hline Fabricated Metal3 & 333 & 253 & 902 & 28.0 \\
\hline Non-metal Minerals & 82 & 55 & 349 & 15.8 \\
\hline Others & 2 & 2 & 29 & 7.4 \\
\hline
\end{tabular}

Notes: 1. Classification is based on Customs Import Tariff of the Republic of China (CTRN) code, at 8-digit level. Some CTRN code appears in more than one sector, making the total number of concessions added up from this table greater than the total number of granted concessions shown in table 3 .

2. Number of concessions is greater than tariff items affected because some concessions were made repetitively. 3. Fabricated metal includes machinery, electronics and transport equipment. 
Table 5

Limited Dependent Variable Model for Tariff Concessions dependent variable: proportion of tariff items designated for tariff cut (in percentage)

\begin{tabular}{|c|c|c|}
\hline \multirow[t]{2}{*}{ Explanatory Variables } & \multicolumn{2}{|c|}{ Coefficient Estimates } \\
\hline & $\begin{array}{l}\text { U.S. Demand for } \\
\text { concessions } \\
1986-1989\end{array}$ & $\begin{array}{l}\text { Final } \\
\text { concessions } \\
1978-1989\end{array}$ \\
\hline Constant & $\begin{array}{r}-103.89 \\
(2.2) * * \\
\end{array}$ & $\begin{array}{l}35.38 \\
(2.6) * \star\end{array}$ \\
\hline PUB & $\begin{array}{l}-0.101 \\
(2.2) * *\end{array}$ & $\begin{array}{l}-0.081 \\
(2.9) * \star\end{array}$ \\
\hline EMP & $\begin{array}{l}0.389 \\
(0.4)\end{array}$ & $\begin{array}{l}-1.012 \\
(1.5) \\
\end{array}$ \\
\hline WAGE & $\begin{array}{c}9.252 \\
(2.3) * *\end{array}$ & $\begin{array}{l}-2.631 \\
(2.3) * \star\end{array}$ \\
\hline $\mathrm{TB}$ & $\begin{array}{c}0.399 \\
(4.3) * *\end{array}$ & $\begin{array}{l}0.087 \\
(1.3) \\
\end{array}$ \\
\hline NTB & $\begin{array}{c}0.233 \\
(3.5) * *\end{array}$ & $\begin{array}{r}0.097 \\
(1.9) * \\
\end{array}$ \\
\hline UTB & $\begin{array}{l}-1.396 \\
(1.3)\end{array}$ & $\begin{array}{l}-1.835 \\
(2.5) * *\end{array}$ \\
\hline UERP & $\begin{array}{l}3.281 \\
(1.6) \\
\end{array}$ & $\begin{array}{c}3.620 \\
(2.5) * \star\end{array}$ \\
\hline UCR4 & $\begin{array}{l}0.059 \\
(1.2)\end{array}$ & $\begin{array}{r}0.068 \\
(1.9) *\end{array}$ \\
\hline URCA & $\begin{array}{c}0.051 \\
(3.4) * *\end{array}$ & $\begin{array}{r}0.020 \\
(1.8) * \\
\end{array}$ \\
\hline log-likelihood & 85.05 & 141.9 \\
\hline
\end{tabular}

Note: Numbers in parentheses are asymptotic-t statistics, * indicates asymptotically significant at 108 level, * * indicates asymptotically significant at $5 \%$ level. 


\section{Footnotes}

1 Compliance with an investigation by the U.S. authorities in terms of providing detailed operation-related data in computerized form is a real challenge to small exporters (Krueger 1993). Costs of legal proceedings also often exceed the capacity of small exporters. These firms usually exit the U.S. market altogether when an affirmative decision is reached at the preliminary determination stage. They cannot afford the risk of an uncertain dumping margin which may eventually be imposed on them in final determination.

2 Toyota later made a smaller-scale investment in 1989 with no export performance commitment. The cars assembled under the project were all sold domestically.

3 Li (1994) argues that confrontation is likely to arise when preference distribution on both sides is homogeneous and when societal pressure is great. Homogeneous preference distribution (lack of opposition) and societal pressure (strong lobbying) eliminate room for compromise. He categorizes the issues of agriculture and intellectual property rights in Taiwan-U.S. talks as being in this category.

4 Ito (1993) argues that, in the case of Japan, businesses which lost vested interests under U.S. pressure are those which sided with Japan's ruling party (LDP) and the U.S. in ideology. The situation is similar in Taiwan, where the losers are big 
private firms politically tied to the ruling party (KMT) and enterprises that are owned outright by the state and the ruling party .

5 Granting exclusive market access to American firms may also forge partnerships between those American producers and Taiwan's state- and party-owned enterprises, carrying political implications.

6 As admission to WTO needs to be unanimously approved by WTO members, the U.S. took the opportunity to produce a lengthy list of demands for liberalization and policy changes. The package was aimed at removing all remaining trade impediments in Taiwan. In previous negotiations which were termed "informal consultations," the U.S. negotiators had addressed the issues in a piecemeal and incremental manner, whereby a partial concession by Taiwan might be accepted with the expectation that further progress could be made in future negotiations. The negotiation pertinent to WTO admission is a one-shot deal and the incrementalism principle was abandoned.

7 Average tariff burden is derived by dividing the tariff revenue by the value of total imports. 


\section{Appendix}

\section{Sources of Data}

Pub: The share of public enterprises in agricultural production is calculated from the Report on Agriculture and Fishery Census, Taiwan-Fukien District, the Republic of China, 1980, 1985, 1990, ROC Directorate-General of Budget, Accounting, and statistics (DGBAS), and those in manufactured output from Kung ch'ang chiao cheng chi ying yun tiao ch'a pao kao (Survey on Factory Registrations and Operations), ROC Ministry of Economic Affairs.

WAGE: Wages of manufacturing workers are from Yearbook of Earning and Productivity statistics, Taiwan Area, ROC, 1993, DGBAS; wages of agricultural workers from Report on the survey of Family Income \& Expenditure, Taiwan Province, ROC, 1993, DGBAS, Taiwan Provincial Government.

EMP: Employment size of manufacturing sectors is from yearbook of Earnings and Productivity Statistics, Taiwan Area, ROC, 1993, DGBAS; employment size of agricultural sectors from Agricultural Production Statistics Abstract, Taiwan District, the Republic of China, 1993, ROC Council of Agriculture.

TB: Average nominal tariffs are based on 1986 levels and calculated from Customs Import Tariffs and classification of Import \& export Commodities of the Republic of China, ROC Ministry of Finance.

NTB: Non-tariff barrier index is also based on 1986 levels. NTB is a weighted index of five forms of trade barriers, i.e., prohibition and control, producer-only import restriction, public-enterprise only import restriction, sources-of-import restriction, administrative licensing control. For details of calculation, see Chen and Hou(1993).

CR4: Four-firm concentration ratio is calculated from 1986 Industrial and Commercial Census (databank), DGBAS.

UTB: U.S. concessions in nominal tariffs in the Tokyo Round are from Allan Deardorff and Robert Stern "The Effect of Tokyo 
Round on the Structure of Protection" in Robert Baldwin and Anne Krueger (eds.), The structure and Evolution of Recent U.S. Trade Policy, Chicago, University of Chicago Press (1984).

UERP: Same as UTB.

UCR4: Four-firm concentration ratios are form 1987 Census of Manufactures, U.S. Department of Commerce. 


\section{References}

Aw, Bee-Yan, 1993, Price Discrimination and Markups in Export Markets, "Journal of Development Economics", 42,315-336.

Aw, Bee-Yan and Mark Roberts, 1986, "Measuring Quality Change in Quota-Constrained Import Market: the Case of U.S. Footwear," Journal of International Economics, 21, pp, 45-60

Balassa, Bela, 1977, "Revealed Comparative Advantage Revisited:

An Analysis of Relative Export Shares of the Industrial Countries: 1953-1971," Manchester School of Economic and Social studies, $45(4), 327-344$.

Baldwin, Robert, 1971, "Determinants of The Commodity structure of U.S. Trade," American Economic Review, 61, 126-146.

Baldwin, Robert, 1989, "The Political Economy of Trade Policy," Journal of Economic Perspectives, 3 (4), 119-135.

Baldwin, Robert, Tain-Jy Chen and Douglas Nelson, 1995, The Political Economy of U.S. - Taiwan Trade, Ann Arber : University of Michigan Press.

Boltuck, Richard and Robert Litan, (eds.) 1991, Down in the Dumps, Washington, DC: Brookings Institution.

Chen, Tain-Jy and Chi-ming Hou, 1993, "The Political Economy of Trade Protection in the Republic of China on Taiwan," in Takatoshi Ito and Anne Krueger (eds.) Trade and Protectionism, Chicago: University of Chicago Press.

Chen, Tain-Jy and Meng-Chun Liu, 1993, "Tai-wan mou-i po hu tse hsin chen (Determinants of Trade Protection in Taiwan) Academic Papers, 21(1), 1-30.

cline, william, 1990, The Future World Trade in Textiles and Apparel, Washington, DC: Institute for International Economics.

de Melo, Jaime and David Tarr, 1990, "Welfare Costs of U.S. Quotas in Textiles, steel, and Autos," Discussion Paper 401, London: Center for Economic Policy Research.

Falvey, Rodney, 1979, "The Composition of Trade within ImportRestricted Product Categories", Journal of Political Economy, 


\section{7, 1105-1114.}

Feenstra, Rober C., 1984, "Voluntary Export Restraints in U.S. Autos, 1980-1981: Quality, Employment, and Welfare Effects," in: R.E. Baldwin and A.O. Kruger (eds.) The structure and Evolution of Recent U.S. Trade Policy, Chicago: University of Chicago Press, 35-59.

Harris, Richard, 1985, "Why Voluntary Export Restraints are 'Voluntary'," Canadian Journal of Economics, 18, 799-809. Hufbauer, Gary, Diane T. Berliner, and Kimberly Ann Elliot, 1986, Trade Protection in the United States, 31 Case Studies, Washington, D.C.: Institute for International Economics.

Ito, Takatoshi, 1993, "U.S. Policy Pressure and Economic Liberalization in East Asia," in Jeffery Frankel and Miles Kahler(eds.) Regionalism and Rivalry: Japan and the United States in Pacific Asia, Chicago: University of Chicago Press, 394-420.

Keesing, Donald, 1966, "Labor Skills and Comparative Advantage," American Economic Review, 56, 249-294.

Krueger, Anne, 1993, Economic Policies at Cross-Purposes, Washington, DC: Brookings Institution.

Li, Chien-pin, 1994, "Trade Negotiation between the United States and Taiwan, "Asian Survey, 34 (8), 692-705.

Nam, Chong-Hyun, 1993, "Projectionist U.S. Trade Policy and Korean Exports," in Takatoshi Ito and Anne Krueger(eds.) Trade and Protectionism, Chicago: University of Chicago Press, 183-218.

Olson, Mancur, 1965, The Logic of Collective Action: Public Goods and the Theory of Groups, Cambridge, Mass,: Harvard University Press.

Ries, John, 1993 "Windfall Profits and Vertical Relationships Who Gained in the Japanese Auto Industry from VER," Journal of Industrial Economics, 41(3), 259-276. 
2 Toyota later made a smaller-scale investment in 1989 with no export performance commitment. The cars assembled under the project were entirely sold domestically.

5 Exclusive market access to American firms may also forge partnership between American firms and Taiwan's state-and party-owned enterprise, carrying political implications.

6 As admission to GATT needs to be unanimously approved by GATT members, the U.S. took the opportunity to produce a lengthy list of demand for liberalization and policy changes. The package was aimed at removing all remaining trade impediments in Taiwan. In previous negotiations which were trend " informal consultations ", the U.S. negotiators addressed the issues by a piecemeal approach whereby a partial concession by Taiwan might be accepted with the expectation that further progress can be made in future negotiations. The negotiation pertinent to admission is a one-shot process.

7 Average tariff burden is derived by dividing the tariff revenue by the value of total imports. 